\title{
Leaf spot of Hosta ventricosa caused by Fusarium oxysporum in China
}

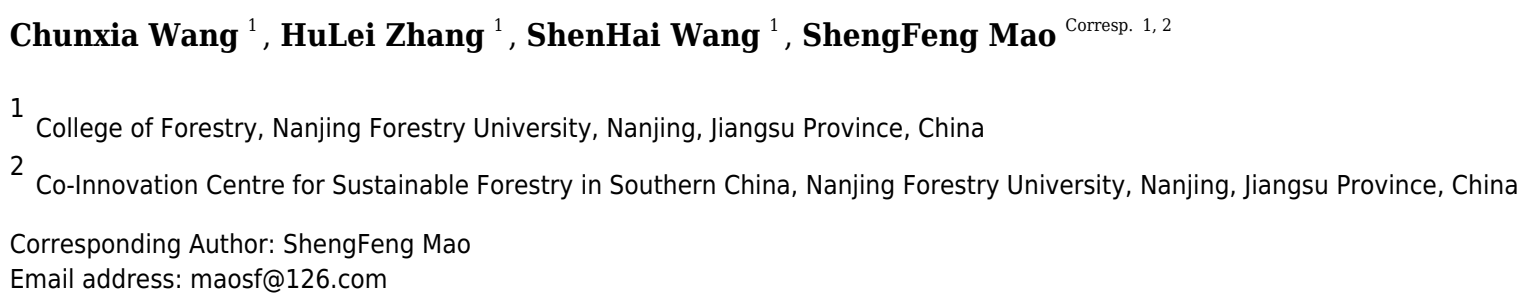

Leaf spot of Hosta ventricosa is a new disease in China. This disease seriously affects the ornamental value and greening function of $H$. ventricosa. Identification of the causal agent can prevent and control leaf spot in $\mathrm{H}$. ventricosa and promote the healthy development of the $H$. ventricosa industry. Known incidents of leaf spot of $H$. ventricosa occurred in three places, and samples were collected. After the fungus were isolated, its pathogenicity was tested according to Koch's postulates. Isolates ZE-1b and ZE-2b were identified as Fusarium oxysporum based on morphological features and multigene phylogenetic analyses of calmodulin (CMDA), RNA polymerase II subunit A(RPB1), RNA polymerase II second largest subunit (RPB2) and translation elongation factor 1-alpha (TEF1). These results provide a theoretical basis for the control of this disease of $H$. ventricosa. 
$1 \quad{ }^{1}$ Leaf spot of Hosta ventricosa caused by Fusarium oxysporum in China

3

$4{ }^{1}$ College of Forestry, Nanjing Forestry University, Nanjing, Jiangsu 210037, China

$5 \quad{ }^{2}$ Co-Innovation Centre for Sustainable Forestry in Southern China, Nanjing Forestry

6 University, Nanjing, Jiangsu 210037, China

8 Leaf spot of Hosta ventricosa is a new disease in China. This disease seriously affects the

9 ornamental value and greening function of $H$. ventricosa. Identification of the causal agent can 10 prevent and control leaf spot in $H$. ventricosa and promote the healthy development of the $H$. 11 ventricosa industry. Known incidents of leaf spot of $H$. ventricosa occurred in three places, and 12 samples were collected. After the fungi were isolated, their pathogenicity was tested according to 13 Koch's postulates. Isolates ZE-1b and ZE-2b were identified as Fusarium oxysporum based on morphological features and multi gene phylogenetic analyses of calmodulin (CMDA), RNA polymerase II subunit A(RPB1), RNA polymerase II second largest subunit (RPB2) and translation elongation factor 1-alpha (TEF1). These results provide a theoretical basis for the control of this disease of $H$. ventricosa.

\section{Introduction}

H. ventricosa, is a perennial herbaceous plant of the Hosta genus in Liliaceae. It originated in China, South Korea and Japan (Yu et al.2015) and is widely distributed in China, including

\footnotetext{
${ }^{1}$ Corresponding author

ShengFeng Mao

maosf@126.com
} 
Jiangsu, Anhui, Hebei and other places (Liu et al., 2008). In addition to its bright leaves and graceful habit, this species has strong adaptability to the environment and is suitable for planting under trees, in the shade of buildings or other exposed shaded places. It is an excellent ground cover with ornamental value and greening functions (Zhao, Chen $\& L v, 2009$ ). In addition, the whole plant, flowers, leaves or roots can be used as a traditional Chinese medicinal material with the ability to dissipate blood stasis and relieve pain (Zeng, Zhao \& Li, 2020).

However, $H$. ventricosa is impacted by several major pathogens, such as Sclerotium rolfsii Sacc. This disease manifests because the $H$. ventricosa leaves are especially thick, and during the rainy season, the $H$. ventricosa rhizome is in contact with water for a prolonged time (Zhao, Chen \& $L v, 2009)$.Thus, the epidermis of the affected area becomes brown and necrotic, and finally a white mycelial layer is formed, which leads to cortex decay ( $L i$, Yang \& Zhu, 2013). In addition, excessive humidity and poor drainage in the rainy season can also favor diseases caused by Colletotrichum, which mainly damages the leaves, petioles and pedicels of $H$. ventricosa. The plants present round or nearly round discolloid spots that are gray or grayish brown (Zhao, Chen $\& L v, 2009$ ). Leaf spot of $H$. ventricosa caused by $F$. oxysporum is a very serious fungal disease (Fisher et al., 2012). F. oxysporum is one of the top ten most important plant pathogenic fungi in the world, with high virulence and a wide distribution area. The pathogen can cause plant drying and wilting. F. oxysporum can be a saprophytic or parasitic fungus. It is widely found in nature, animals and plants, and has been isolated in cold Arctic areas and arid deserts. This strain can cause wilt and decay of roots, stems, leaves, flowers and fruits in over one hundred plant hosts (Maryani et al., 2019).

\section{Materials and methods}

\section{Experimental materials}

Leaves of infected $H$. ventricosa were collected in Nanjing from 2020 to 2021. Materials used in this study included PDA plates, tissue separation tools, 2\% CTAB, and chloroform. 


\section{Sampling and isolation}

To isolate the fungus, $H$. ventricose leaves showing leaf spots were collected from three places in Nanjing, China $\left(32^{\circ} 4^{\prime} 47^{\prime \prime} \mathrm{N}, 118^{\circ} 48^{\prime} 31^{\prime \prime} \mathrm{E} ; 32^{\circ} 4^{\prime} 45^{\prime \prime} \mathrm{N}, 118^{\circ} 48^{\prime} 31^{\prime \prime} \mathrm{E} ; 32^{\circ} 4^{\prime} 44^{\prime \prime} \mathrm{N}, 118^{\circ} 48^{\prime} 31^{\prime \prime} \mathrm{E}\right.$.), in September 2020. The collected leaves were rinsed under tap water for 15-30 min. After the leaves were dried, both healthy and affected tissues were cut into small pieces, each of which was $2 \times 2 \mathrm{~mm}$ in size. The pieces were disinfected in $75 \%$ ethanol for $30 \mathrm{~s}$ and in $2 \% \mathrm{NaClO}$ for $90 \mathrm{~s}$, then rinsed with sterile water 3 times for $20 \mathrm{~s}$ each time (Si et al., 2021), dried on sterile filter paper and inoculated onto PDA. After the appearance of fungal colonies, blocks of tissue were removed from the edges of the colonies for purification. The morphological characteristics, color, size and shape of the purified colonies were observed and described (Chang et al., 2020). Two single-spore cultures were used for further study and were also deposited in the China Forestry Culture Collection Center (CFCC).

\section{Pathogenicity test}

The experiments were replicated three times, and a total of 30 seedings were used. Healthy $H$. ventricosa leaves were collected and rinsed with clean water. The leaves surface were disinfected and dried on an aseptic bench. Pathogenic isolates were inoculated on PDA plates and cultured in an incubator at $25^{\circ} \mathrm{C}$ for 5 days. To test the pathogenicity of the isolates, $H$. ventricosa leaves were wounded with a sterile needle and then inoculated with $5 \mathrm{~mm}$ plugs cut out from the growing edges of 5-day-old cultures (Feng et al., 2019). Three replicates were used (Yang et al., 2021). At the same time, isolates were inoculated onto plants in the natural environment in the wild. Leaves mock inoculated without isolates were used as controls, and the incidence of leaf spot was observed after three days (Yang et al., 2021).

\section{Morphological analysis}

Pathogenic isolates were inoculated on PDA plates and incubated in an incubator at $25^{\circ} \mathrm{C}$ for one week to observe and record the morphology, color, surface characteristics and growth status at the edges of the colonies (Zhang, 2014). The morphology, size and presence of spore septations 
were recorded under a microscope (Murugan et al., 2020).

DNA extraction, amplification, sequencing and phylogenetic analyses

Before DNA extraction, a small portion of mycelia taken from a 7-day-old culture of the pathogen grown on PDA plates at $25^{\circ} \mathrm{C}$ was collected and transferred to 2-ml Eppendorf tubes. Genomic DNA was extracted by the CTAB method (Freeman et al., 1996). After passing the test, the mycelia were stored at $-18^{\circ} \mathrm{C}$ (Guo, Hyde \& Liew, 2000; Sahai-Maroof et al., 1984).

The extracted DNA was subjected to polymerase chain reaction (PCR) amplification of partial regions of five genes/regions, namely, calmodulin (CMDA), RNA polymerase II subunit A (RPB1), RNA polymerase II second largest subunit (RPB2) and translation elongation factor 1alpha (TEF1), which were amplified with primers CL1/CL2A, FA/G2R, 5F2/7CR, and EF1/EF2, respectively (Table 1).

The total volume of the PCR mixture was 50 $\mu \mathrm{L}$ (Lombard, Van \& Crous, 2019), containing 19 $\mu \mathrm{L}$ double-distilled water, $2 \mu \mathrm{L}$ genomic DNA, $2 \mu \mathrm{L}$ of each primer, and $25 \mu \mathrm{L}$ Taq DNA polymerase mix. After PCR, the products were sent to Shanghai Jieli Biotechnology Co., Ltd. for DNA sequencing. All sequences with primers CL1/CL2A, FA/G2R, 5F2/7CR, and EF1/EF2 of ZE-1b was deposited in GenBank under accession numbers MW890756, MZ146450, MW890757, MZ088053, and ZE-2b was deposited in GenBank under accession numbers MW885175, MZ127817, MZ126726 and MW885176, respectively.

The CAMD, RPB1, RPB2, and TEF sequences were compared to sequences in GenBank using BLAST. The sequences were obtained from GenBank for phylogenetic analyses (Table 2). We downloaded sequences for which the comparison results showed higher than $99 \%$ similarity. Using Fusarium aywerte as the outgroup. The arrangement of each gene/region was compared with MAFFTver.7.313 (Katoh \& Standley, 2013) and manually adjusted with BioEditver.7.0 (Hall, 1999). It was a combination of these five genes/regions. The ModelFinder was used to select the best-fit model (Kalyaanamoorthy et al., 2017). In IQTree ver.1.6.8, the alternative model of GTR + F + I + G4 was adopted, 1000 iteration guidance methods were used, 
98

99

100

101

102

103

104

105

106

107

108

109

110

111

112

113

114

115

116

117

118

119

120

121

122

and the maximum - likelihood ground method (ML) analysis was used to estimate the system relationship (Nguyen et al., 2015). In the GTR $+\mathrm{I}+\mathrm{G}+\mathrm{F}$ model (2 parallel runs, 2 million generations), MRBayesver.3.2.6 was used for Bayesian analysis. Using burn-in, 25\% of sampled data were discard (Ronquist et al., 2012). The phylogenetic trees were drawn with FigTree ver. 1.4.4 (http://tree.bio.ed.ac.uk/soft- ware/figtree/)

\section{Results}

\section{Incidence of disease and symptoms}

The incidence of leaf spot of $H$. ventricosa in three areas of Nanjing City was investigated, and the results showed that the incidence of leaf spot of $H$. ventricosa in the field was $40 \%$. When the $H$. ventricosa leaves were infected, the edge of leaves will turn green and yellow, and be dull. With the development of disease, the leaf spots extended and gradually turned yellowish brown.

\section{Pathogenicity of fungal isolates}

Base on the colony morphology, fifty fungal samples were divided into seven types. More than $50 \%$ are classified as ZE-1b/ZE- $2 \mathrm{~b}$ types. According to the colony morphology, fungi were divided into 7 kinds namely ZE-a - ZE-g. According to the ITS sequence ZE-a - ZE-g were identified as Fusarium oxysporum (50\%), Fusarium ipomoeae (20\%), Fusarium equsiti (10\%), Colletotrichum spaethianum (9\%), Nigrospora spherica (5\%), Colletotrichum gloeosporioide (4\%), Colletotrichum siamense (2\%). All of the seven kinds of isolates were inoculated seedings, replicated three times.

Inoculated $H$. ventricosa showed leaf spot disease consistent with that observed previously. Two isolates (ZE-1b and ZE-2b) were proven pathogenic to H. ventricosa leaves. Lesions appeared on detached leaves 3 days after inoculation using mycelial plugs (Fig. 1G-H). In live plants, one week after inoculation, the leaves began to show obvious symptoms of infection, turning yellow and withering (Fig. 1D-E). In addition, no lesions were observed on leaves from the control plants (Cong et al., 2017) (Fig. 1C, F). The symptoms on detached leaves and live plants after 
123

124

125

126

127

128

129

130

131

132

133

134

135

136

137

inoculation were the same as those in the field (Fig. 1A-B). The reisolated pathogens from inoculated diseased leaves were consistent with those obtained in the first isolation. Therefore, it was determined that ZE-1b and ZE-2b were the main pathogens causing $H$. ventricosa leaf spot.

\section{Morphological characteristics of fungal isolates}

Morphological observations of the pathogenic fungi were carried out. Colonies were inoculated on PDA plates and cultured at $25^{\circ} \mathrm{C}$ for 4 days, and the colony diameter was $7 \mathrm{~cm}$ (Fig. 2I, N). The hyphae grew radially, luxuriously and densely, and the aerial hyphae were velvety, white or pink-white (Liu et al., 2020).

Fusarium has three types of conidia for reproduction and survival under adverse environments: microconidia, macroconidia, and chlamydospores. Microconidia were numerous, oval or kidneyshaped, and scattered, with the size of $4.7-8.6 \mu \mathrm{m} \times 2.5-4.7 \mu \mathrm{m}$ (Fig. 2J, O). Macroconidia were sickle-shaped, generally symmetrical, slightly curved, and tapering toward the ends, with the size of $23-50.6 \mu \mathrm{m} \times 3-5 \mu \mathrm{m}$ (Fig. $2 \mathrm{~K}, \mathrm{P}$ ). Chlamydospores were readily produced, with smooth and spherical surfaces (Fig. 2L, Q). They were solitary, paired or clustered between hyphae $(D u, 2017)$.

\section{Phylogenetic analyses}

Sequences of the genes/regions CAMD, RPB1, RPB2, and TEF1 from the two isolates (ZE-1b and ZE-2b) were deposited in GenBank, and the accession numbers are shown in Table 2. The sequences from ZE-1b and ZE-2b showed $100 \%$ similarity with $F$. oxysporum. These results further indicate that isolation, purification, morphological identification and molecular biology can be used in combination for accurate and reliable results (Cong et al., 2017).

In the ML phylogenetic tree, two isolates (ZE-1b and ZE-2b) were in the same cluster as $F$. oxysporum with 100\% RAxML bootstrap support values (Fig. 3). The phylogenetic tree obtained by Bayesian analysis was consistent with the ML tree. Bayesian analyses showed that the isolates clustered with $F$. oxysporum with a high Bayesian posterior probability. Two isolates 
148 (ZE-1b and ZE-2b) were identified as $F$. oxysporum based on multigene phylogeny and 149 morphology.

\section{Discussion}

151 In this study, a novel leaf spot disease was studied through pathogenicity determination, 152 morphological identification, and molecular biological identification, and the results showed that 153 the pathogen was $F$. oxysporum. Herein, wilt of $H$. ventricosa leaves caused by $F$. oxysporum 154 was reported for the first time in China.

F. oxysporum is a facultative parasitic fungus that can both infect plants and live in soil (Yang et al., 2021; Cong et al., 2017). The transmission of the isolate is either vertical transmission through the mother line to the next generation of seeds or horizontal transmission when the fungi in soil or crops infects the host through wounds. The main means of horizontal transmission are as follows: fungal isolates infect and destroy the vascular bundle from the roots (Foley, 1962) and stems of the plant and spread to various parts of the plant. Due to the exposure of stomata and other external tissues of crops as well as plant wounds, spore and mycelial infection via the air can also occur (Headrick, 1991). Most Fusarium enter through natural openings in plants or seeds, such as stomata (Lin et al., 2014).

F. oxysporum is highly destructive and can destroy many plant organs and cause very severe diseases, such as leaf spot, root rot, stem rot, flower rot and grain wilt (Liu et al., 2020). Globally, F. oxysporum has been identified as a wilt pathogen in many host plants, such as bananas (Maryani et al., 2019; Forsyth, Smith \& Aitken, 2006) , cotton (Xie et al., 2020; Davis et al., 2006; Zhu et al., 2020), cucumbers (Jaber et al., 2020), sesame (Khalifa, 1997), grapes (ElSayed et al., 2011), basil (Chen, Lin \& Chung, 2017; Mamta et al., 2013; Salim, Salman \& Jasim, 2017; Basco et al., 2017), lettuce (Guerrero et al., 2020) and pecan (Rolom et al., 2020). Leaves wilt and eventually drop to the ground, leading to a large area of growth decline; at worst, the whole plant winters and dies, which eventually leads to reductions in yield and quality, causing huge economic losses (Yang et al., 2021; Li et al., 2020; Cong et al., 2017). 
174

175

176

177

178

179

180

181

182

183

184

185

186

187

188

189

190

191

192

193

194

195

196

197

198

Originally by scientists abroad, Fusarium was considered a crescent-shaped fungus born on the seed coat. Because many other fungi also produce such sickle-like spores and fungal culture techniques have limitations, the classification of Fusarium has long been in a state of confusion. Later, German scientists introduced the first systematic classification of Fusarium and proposed a relatively complete classification system based on the biological characteristics of these fungi, combined with their morphological structures, which laid the foundation for classification research on Fusarium (Du, 2017). Fusarium was initially divided into 44 strains, with 35 strains in China, laying a foundation for the study of Fusarium here $(Y u, 1977)$. Currently, more than 3000 strains of Fusarium have been studied, 40 physiological strains have been identified and collected, and 1 new strain was found. Twenty-eight strains of Fusarium zhejiangensis were identified in Zhejiang, and Fusarium zhejiangensis was first recorded in the literature. "Fusarium disease in Taiwan" was published in Plant Pathology, Chung Hsing University, Taiwan (Du, 2017).

In recent years, research on Fusarium taxonomy in China has developed rapidly based on both morphology and molecular biology. This experiment provides a basis for field prevention and treatment of $H$. ventricosa leaf spot caused by Fusarium and provides a reference for further genetic analysis and cultivation of disease resistant varieties of $H$. ventricosa $(Z h i, 2020)$.

\section{Conclusion}

This is the first report of $H$. ventricosa leaf spot in China and Chinese $H$. ventricosa is a new host of $F$. oxysporum. We should take reasonable preventive measures against diseases. This study provided theoretical guidance for the control of Chinese $H$. ventricosa leaf spot.

\section{Additional Information and Declarations}

\section{Funding}

This research was financially supported by the second batch of ideological and political demonstration courses

of

Nanjing

Forestry

University. 


\section{Reference}

Basco MJ, Bisen K, Keswani C, Singh HB. 2017. Biological management of Fusarium wilt of tomato using biofortified vermicompost. Mycosphere 8:467-83 DOI 10.5943/mycosphere/8/3/8.

Chang WJ, Li H, Chen HQ, Qiao F, Zeng HC. 2020. NBS-LRR gene family in banana (Musa acuminata): genome-wide identification and responses to Fusarium oxysporum $\mathrm{f}$. sp. cubense race 1 and tropical race 4. European Journal of Plant Pathology 157:549-63 DOI 10.1007/s10658-020-02016-7.

Chen YJ, Lin YS, Chung WH. 2017. Fusarium wilt of basil caused by Fusarium oxysporum f. sp. basilici in Taiwan. Plant disease 98:1432 DOI 10.1094/PDIS-03-14-0243-PDN.

Cong LL. 2017. Identification of Alfalfa (Medicago sativa L.) Fusarium Root Resistant Cultivars and Proteomic Analysis of Alfalfa Response to Fusarium proliferatum. D.AG. China Agricultural University.

Davis RM, Colyer PD, Rothrock CS, Kochman JK. 2006. Fusarium Wilt of Cotton: Population Diversity and Implications for Management. Plant disease 90:692-703 DOI 10.1094/PD-90-0692.

Du B. 2017. Classification and research status of Fusarium. Journal of Taiyuan University (Natural Science Edition) 35:68-70 DOI 10.14152/j.cnki.2096-191X.2017.04.017.

El-Sayed H, Ziedan, El-Sayed M. Embaby, Eman S, Farrag. 2011. First record of Fusarium vascular wilt on grapevine in Egypt. Archives Of Phytopathology And Plant Protection 44:1719-1727 10.1080/03235408.2010.522818.

Feng Y, Xie ZS, Ou ZK, Liu SM, Xie CM, Chen PJ, Han QX. 2019. Study on Passiflora edulia Disease Induced by Fusarium oxysporum. Journal of Zhongkai University of Agriculture and Engineering 32:13-18.

Fisher MC, Henk DA, Briggs CJ, Brownstein JS, Madoff LC, McCraw SL, Gurr SJ. 2012. Emerging fungal threats to animal, plant and ecosystem health. Nature 484:186-94 DOI 10.1038/nature10947.

Foley DC. 1962. Systemic infection of corn by Fusarium moniliforme. Phytopathology52:870-872.

Forsyth LM, Smith LJ, Aitken EAB. 2006. Identification and characterization of non-pathogenic Fusarium oxysporum capable of increasing and decreasing Fusarium wilt severity. Mycological Research 110: 929-35 DOI 10.1016/j.mycres.2006.03.008.

FreemanS, KatanT, ShabiE. 1996. Characterization of Colletotrichum gloeosporioides isolates from avocado and almond fruits with molecular and pathogenicity tests. Applied and Environmental Microbiology 62:1014-1020 DOI 10.1089/oli.1.1996.6.69.

Guerrero MM, Martinez MC, Leon M, Armengol J, Monserrat A. 2020. First Report of Fusarium Wilt of Lettuce Caused by Fusarium oxysporum f. sp. lactucae Race 1 in Spain. Plant Disease 104:1858-58Ｄ DOI 10.1094/Pdis-10-192143-Pdn. 
230 Guo LD, Hyde KD, Liew ECY. 2000. Identification of endophytic fungi from Livistona chinensis based on morphology and rDNA sequences. New Phytol 147:617-30 DOI 10.1046/j.1469-8137.2000.00716.x.

Hall T A. 1999. BioEdit: A User-Friendly Biological Sequence Alignment Editor and Analysis Program for Windows 95/98/NT. Nucl Acids Symp Seri 41:95-98 DOI 10.1021/bk-1999-0734.ch008.

Headrick JM. 1991. Maternal influence on the resistance of sweet corn lines to kernel infection by Fusarium moniliforme. Phytopathology 44:13-23 DOI 10.1094/Phyto-81-268.

Jaber R,Planchon A, Mathieu RE, Kiefer MMC, Zahid A, Plasson C, Pamlard O, Beaupierre S, Trouvé JP, Guillou C, Driouich A, Follet GML, Mollet JC. 2020. Identification of two compounds able to improve flax resistance towards Fusarium oxysporum infection. Journal of Plant Sciences 301:110690 DOI 10.1016/J.PLANTSCI.2020.110690.

Kalyaanamoorthy S , Minh BQ , Wong TKF , Haeseler AV , Jermiin LS. 2017. ModelFinder: Fast Model Selection for Accurate Phylogenetic Estimates. NatMethods 14:587-589 DOI 10.1038/nmeth.4285.

Katoh K, Standley DM. 2013. MAFFT multiple sequence alignment software version 7: improvements in performance and usability. Molecular Biology and Evolution 30:772-780 DOI 10.1093/molbev/mst010.

Khalifa M. 1997. Studies on root-rot and wilt diseases of sesame (sesamum indicum L.)

Li L, Yang J, Yuan HL, Zhu XX. 2013. Research progress of medicinal ornamental plant, Hosta ventricosa. Journal of Suzhou University 28:96-98.

Li QL, Yang Y, Xiao Z, Cao M, Han F. 2020. Screening and identification of biocontrol bacteria against root rot of Amaranthus sinensis. Journal of Southwest University (Natural science Edition) 42(09) DO 10.13718/j.cnki.xdzk.2020.09.008.

Lin ZY, Que YX, Liu PW, Huang YZ, Zhang MQ. 2014. Research progress of plant pathogenic fusarium. Sugar Crops of China 1:58-64+78 DOI 10.13570/j.cnki.scc.2014.01.004.

Liu XL, Luo JD, Tang XH, Rui RT, Mu J. 2008. The propagation and application of Hosta ventricosa. Southern Agriculture (Garden Flower Edition) 4:76-77 DOI CNKI:SUN:NFLH.0.2008-04-029.

Lombard L, Sandoval-Denis M, Lamprecht SC, Crous PW. 2019. Epitypification of Fusarium oxysporum clearing the taxonomic chaos. Persoonia 43:1-47 DOI10.3767/persoonia.2019.43.01.

Lombard L, Van DR,Crous PW.2019. Neotypification of Fusarium chlamydosporuma reappraisal of a clinically important species complex. Fungal systematics and evolution 4:183-200 DOI 10.3114/fuse.2019.04.10.

Mamta J, Rashmi S, Sharma AK, Anil P. 2013. Isolation and characterization of Fusarium oxysporum, a wilt causing fungus, for its pathogenic and non-pathogenic nature in tomato (Solanum lycopersicum). Journal of Applied and Natural Science 5:108-117 DOI 10.31018/jans.v5i1.290. 
261

Maryani N, Lombard L, Poerba YS, Subandiyah S, Crous PW, Kema GHJ. 2019. Phylogeny and genetic diversity of the banana Fusarium wilt pathogen Fusarium oxysporum f. sp. cubense in the Indonesian centre of origin. Studies in Mycology 92:154-194 DOI 10.1016/j.simyco.2018.06.003.

Murugan L, Krishnan N, Venkataravanappa V, Saha S, Mishra AK, Sharma BK, Rai AB. 2020. Molecular characterization and race identification of Fusarium oxysporum $\mathrm{f}$. sp. lycopersici infecting tomato in India. 3 Biotech 11:486-486 DOI ARTN 48610.1007/s13205-020-02475-z.

Nguyen LT, Schmidt HA, von Haeseler A, Minh BQ. 2015. IQ-TREE: a fast and effective stochastic algorithm for estimating maximum-likelihood phylogenies. MolBiolEvol 32:268-274 DOI 10.1093/molbev/msu300.

O'Donnell K, Corby KH, Elizabeth C, Ploetz RC. 1998. Multiple evolutionary origins of the fungus causing Panama disease of banana: Concordant evidence from nuclear and mitochondrial gene genealogies. Proceedings of the National Academy of Sciences 95:2044-2049 DOI 10.1073/pnas.95.5.2044.

O'Donnell K, Sutton DA, Rinaldi MG, Sarver BAJ, Balajee SA, Schroers HJ, Summerbell RC, Robert VARG, Crous PW, Zhang N, Aoki T, Jung K, Park J, Lee YH, Kang S, Park B, Geiser DM. 2010. Internet Accessible DNA Sequence Database for Identifying Fusaria from Human and Animal Infections. Journal of Clinical Microbiology 48:3708-18 DOI 10.1128/Jcm.00989-10.

Rolim JM, Savian LG, Walker C, Blume E, Muniz MFB, Poletto T, Silva MD, da Silva EL, Rabuske JE, Sarzi JS. 2020. First Report of Fusarium Wilt Caused by Fusarium oxysporum on Pecan in Brazil. Plant Disease 104:1870-71 DOI 10.1094/Pdis-09-19-1956-Pdn.

Ronquist F, Teslenko M, vander Mark P, Ayres DL, Darling A, Hohna S, Larget B, Liu L, Suchard MA, Huelsenbeck JP. 2012. MrBayes3.2: efficient Bayesian phylogenetic inference and model choice across a large model space. SystBiol 61:539-542 DOI org/10.1093/sysbio/sys029.

Saghai-Maroof MA, Soliman KM, Jorgensen RA, Allard RW. 1984. Ribosomal DNA spacer-length polymorphisms in barley: mendelian inheritance, chromosomal location, and population dynamics. Proc Natl Acad Sci USA 81:8014-8018 DOI 10.1073/pnas.81.24.8014.

Salim HA, Salman IS, Jasim BN. 2017. IPM approach for the management of wilt disease caused by Fusarium oxysporum f. sp. lycopersici on tomato (Lycopersicon esculentum). Journal of Experimental Biology and Agricultural Sciences 4:742-747

Si YZ, Sun JW, Li DW, Huang L, Ju Y, Zhu LH. 2021. Leaf spot of Sapindus mukorossi caused by Diaporthe biconispora in China. Australasian Plant Pathology 50:193-202 DOI 10.1007/s13313-020-00762-0.

Xie AN, Xu HF, Zhang ZL, Wei T, She YP, Liu XR, Shi HA. 2020. Research progress of pathogenic fusarium. Journal of Hubei Engineering University 40:39-43.

Yang RX, Liu P, Wang YT, Feng WJ, Huang XC, Wang YD. 2021. Isolation and Identification of Pathogenic Bacteria of Peony root rot in Luoyang. Northern Horticulture 1:59-66 DOI 10. 11937/bfyy. 20200399. 
294

295

296

297

298

299

300

301

302

303

304

305

306

307

308

309

310

311

Yang X, Cao S, Yu GY, Wang LL, Tai LM, Zuo YH, Ke XW, Guo YX. 2021. Isolation and identification of pathogenic fungi causing sorghum anthracnose in Heilongjiang Province. Microbiology China 1-11:04-06 DOI 10.13344/j.microbiol.china.200682.

Yu DF. 1977. Taxonomic significance of Fusarium. Acta Microbiologica Sinica 17:163-171

DOI 10.13343/j.cnki.wsxb.1977.02.007.

Yu M, Yu Y, Xu L, Liu HZ, Liu SY. 2015. Advances in the study of Hosta. Northern Horticulture 13:198-201 DOI 10.11937/bfyy.201513055.

Zeng GP, Zhao Z, Li Z. 2020. The Occurrence and Prevention of Pseudostellaria heterophylla Southern Blight in Guizhou. Tillage and Cultivation 40:37-38+41 DOI 10.13605/j.cnki.52-1065/s.2020.06.011.

Zhang CD. 2014. Molecular identification and rapid detection of some Colletotrichum pecies. M.AG. Thesis, Henan Agricultural University.

Zhao GM, Chen YN, Lv ZJ. 2009. The cultivation of Hosta ventricosa. Special Economic Animals and Plants. 12:28 DOI 10.3969/j.issn.1001-4713.2009.11.017.

Zhi XX. 2020. Identification of Fusarium Root Rot Pathogens and Evaluation of Alfalfa (Medicago sativa L.) Fusarium Root Rot-Resistant Germplasm Materials. M.AG. Thesis, Chinese Academy of Agricultural Sciences.

Zhu Y, Lujan PA, Wedegaertner T, Nichols R, Abdelraheem A, Zhang JF, Sanogo S. 2020. First Report of Fusarium oxysporum f. sp. vasinfectum Race 4 Causing Fusarium Wilt of Cotton in New Mexico, USA. Plant Disease 104:588-88 DOI 10.1094/Pdis-06-19-1170-Pdn. 
Figure 1

Pathogenicity in detached leaves and in live plants. 


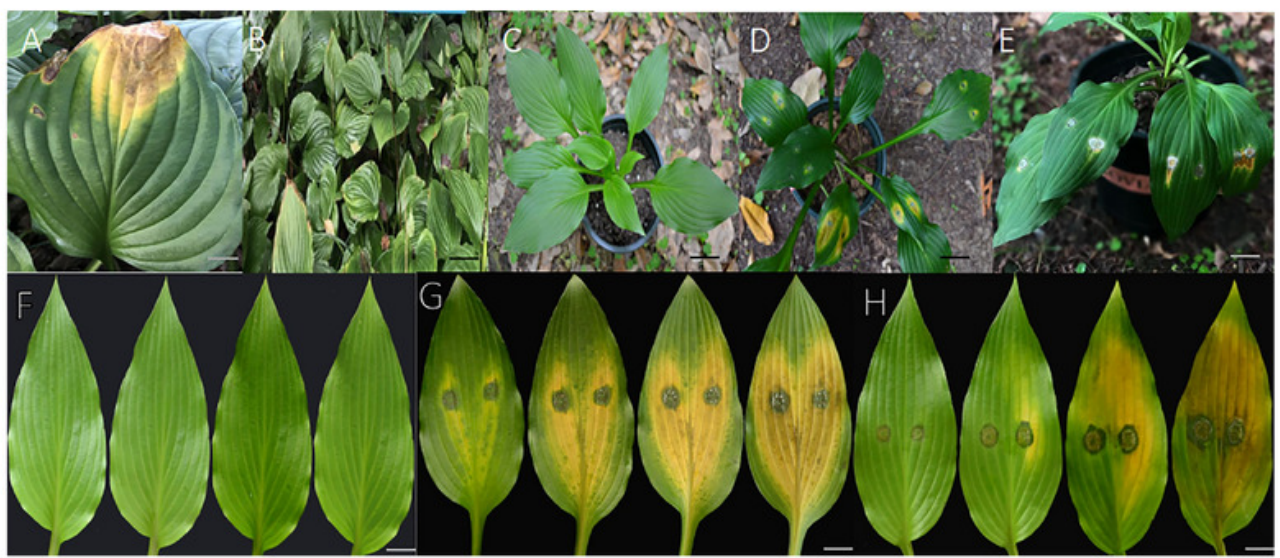

3 (A and B) Diseased leaves naturally infected. (C) No symptoms were observed on

4 leaves from control plants 7 days after inoculation with sterile water; (D) Symptoms on

5 live leaves 7 days after

6 inoculation with mycelial plugs of ZE-1b; (E) Symptoms on live leaves 7 days after

7 inoculation with mycelial plugs of ZE-2b; (F) No symptoms were observed on detached

8 leaves from control plants 3, 5, 7 or 10 days after inoculation with sterile water; $(G)$

9 Symptoms on detached leaves 3, 5, 7 and 10 days after inoculation with mycelial plugs

10 of ZE-1b; (H) Symptoms on detached leaves 3, 5, 7 and 10 days after inoculation with

11 mycelial plugs of $\mathrm{ZE}-2 \mathrm{~b}$; Bars $\mathrm{A}=2 \mathrm{~cm} ; \mathrm{B}=5 \mathrm{~cm} ; \mathrm{C}-\mathrm{E}=3 \mathrm{~cm} ; \mathrm{F}-\mathrm{H}=1 \mathrm{~cm}$. 
Figure 2

The morphology of hyphae and conidia. 
1

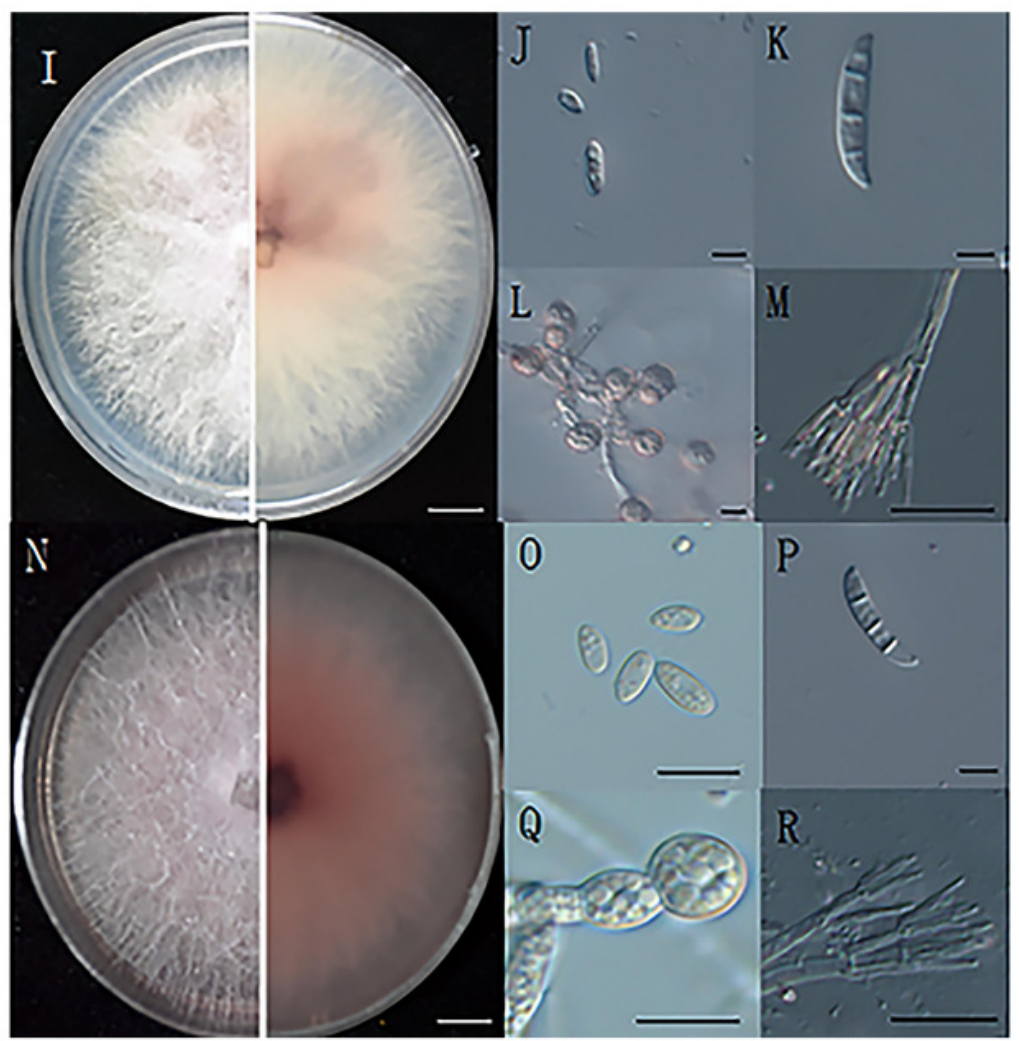

3 (I) The front and reverse colony morphology of ZE-lb; (J) microconidia of ZE-1b; (K) 4 macroconidia of ZE-1b; (L) chlamydospore formation of ZE-1b; (M) conidiophores of ZE-1b; (N) 5 front and reverse colony morphology of ZE-2b; (O) microconidia of ZE-2b; (P) macroconidia of 6 ZE-2b; (Q) chlamydospore formation of ZE-2b; (R) conidiophores of ZE-2b; Bars I, N=1 cm; J-M, $7 \quad \mathrm{O}-\mathrm{R}=10 \mu \mathrm{m}$. 
Figure 3 (on next page)

A maximum parsimony phylogeny for Fusarium oxysporum. 


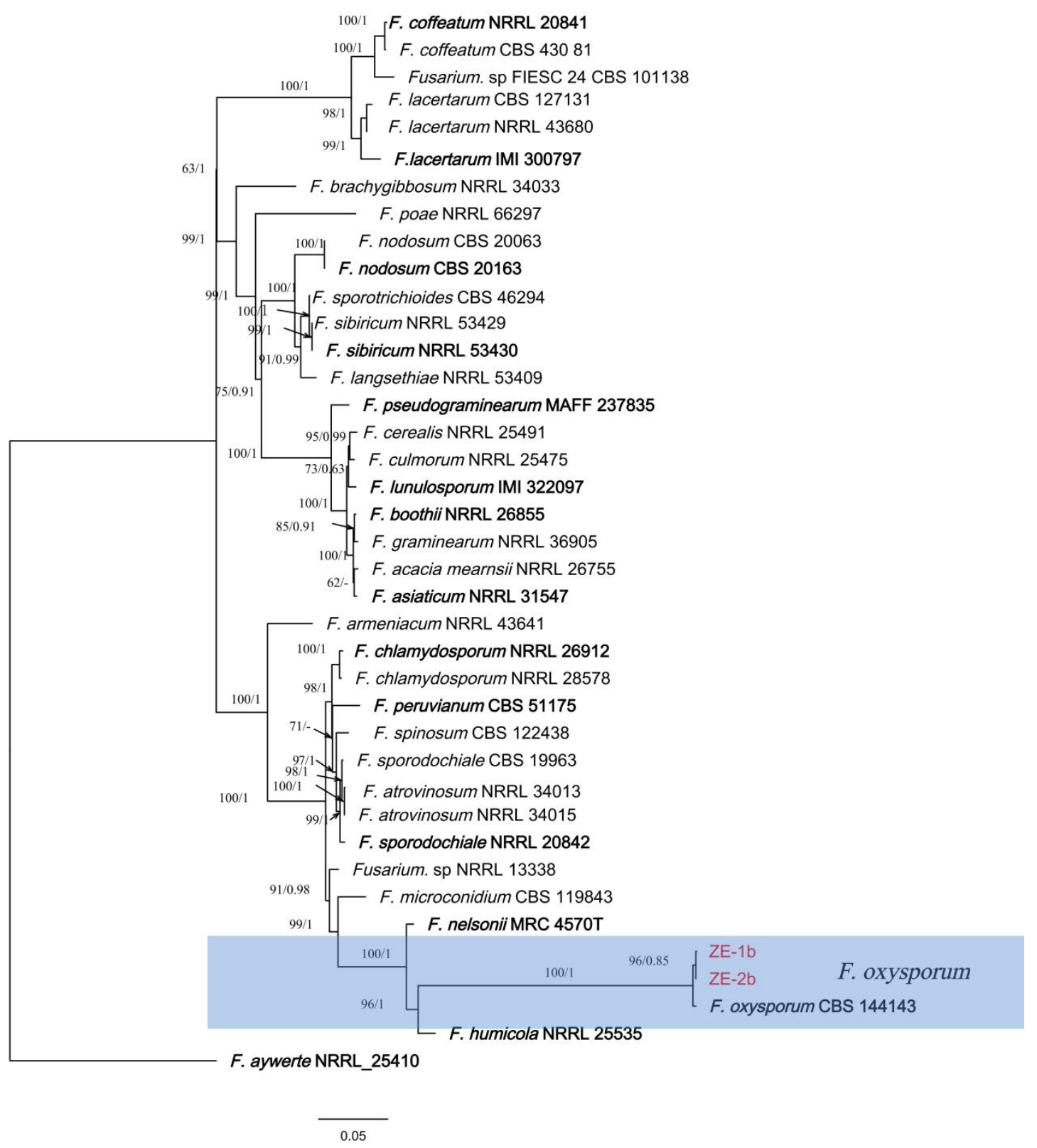

2 Phylogenetic relationship of $\mathrm{ZE}-1 \mathrm{~b}$ and $\mathrm{ZE}-2 \mathrm{~b}$ with related taxa derived from 3 maxmum-likelihood (ML) analysis using combined CAMD, RPB1, RPB2, and TEF

4 sequence alignment of Fusarium spp., With Fusarium aywerte (NRRL 25410) as the 5 outgroup. RAxML bootstrap support values $(\mathrm{ML} \geqslant 50)$ and Bayesian posterior 6 probability $(\mathrm{PP} \geqslant 0.80)$ are shown at the nodes $(\mathrm{ML} / \mathrm{PP})$. Ex-type strains are marked in 7 bold. Isolates from $H$. ventricosa marked in red. 
Table $\mathbf{1}$ (on next page)

Primers for PCR and DNA sequencing. 


\section{Table 1 Primers for PCR and DNA sequencing.}

\begin{tabular}{|c|c|c|c|c|}
\hline \multirow[t]{2}{*}{ Locus } & \multicolumn{2}{|l|}{ Primer } & PCR amplification procedures & Reference \\
\hline & \multicolumn{4}{|c|}{ Designation Sequence $\left(5\right.$ '- $\left.3^{\prime}\right) *$} \\
\hline \multirow[t]{3}{*}{ TEF1 } & EF1 & ATGGGTAAGGARGACAAGAC & $94^{\circ} \mathrm{C}$ to $90 \mathrm{~s}$; Cycles of $94{ }^{\circ} \mathrm{C} 45 \mathrm{~s}, 55^{\circ} \mathrm{C}$ & O'donnell et al., 1998 \\
\hline & EF2 & GGARGTACCAGTSATCATG & $45 \mathrm{~s}, 72{ }^{\circ} \mathrm{C} 1 \mathrm{~min} ; 72^{\circ} \mathrm{C}$ for $10 \mathrm{~min}$; Soak & O'donnell et al., 1998 \\
\hline & & & $10^{\circ} \mathrm{C}$ & \\
\hline \multirow[t]{3}{*}{ CAMD } & CL1 & GARTWCAAGGAGGCCTTCTC & $94{ }^{\circ} \mathrm{C}$ to $90 \mathrm{~s}$; Cycles of $94{ }^{\circ} \mathrm{C} 45 \mathrm{~s}, 55^{\circ} \mathrm{C}$ & Lombard et al., 2019 \\
\hline & CL2A & TTTTTGCATCATGAGTTGGAC & $45 \mathrm{~s}, 72^{\circ} \mathrm{C} 1 \mathrm{~min} ; 72^{\circ} \mathrm{C}$ for $10 \mathrm{~min}$; Soak & Lombard et al., 2019 \\
\hline & & & $10^{\circ} \mathrm{C}$ & \\
\hline \multirow[t]{5}{*}{ RPB1 } & $\mathrm{Fa}$ & CAYAARGARTCYATGATGGGWC & $94^{\circ} \mathrm{C}$ to $90 \mathrm{~s}$; Cycles of $94{ }^{\circ} \mathrm{C} 45 \mathrm{~s}, 58^{\circ} \mathrm{C}$ & O'donnell et al., 2010 \\
\hline & & & $45 \mathrm{~s}, 72{ }^{\circ} \mathrm{C} 2 \mathrm{~min} ;$ Cycles of $94{ }^{\circ} \mathrm{C} 45 \mathrm{~s}, 57$ & \\
\hline & $\mathrm{G} 2 \mathrm{R}$ & GTCATYTGDGTDGCDGGYTCDC & ${ }^{\circ} \mathrm{C} 45 \mathrm{~s}, 72{ }^{\circ} \mathrm{C} 2 \mathrm{~min}$; Cycles of $94{ }^{\circ} \mathrm{C} 45 \mathrm{~s}$ & O'donnell et al., 2010 \\
\hline & & $\mathrm{C}$ & $56{ }^{\circ} \mathrm{C} 45 \mathrm{~s}, 72{ }^{\circ} \mathrm{C} 2 \mathrm{~min} ; 72^{\circ} \mathrm{C}$ for $10 \mathrm{~min}$ & \\
\hline & & & Soak $10^{\circ} \mathrm{C}$ & \\
\hline \multirow[t]{5}{*}{ RPB2 } & $5 \mathrm{~F} 2$ & GGGGWGAYCAGAAGAAGGC & $94{ }^{\circ} \mathrm{C}$ to $90 \mathrm{~s}$; Cycles of $94{ }^{\circ} \mathrm{C} 45 \mathrm{~s}, 58^{\circ} \mathrm{C}$ & O 'donnell et al., 2010 \\
\hline & & & $45 \mathrm{~s}, 72^{\circ} \mathrm{C} 2 \mathrm{~min} ;$ Cycles of $94{ }^{\circ} \mathrm{C} 45 \mathrm{~s}, 57$ & \\
\hline & $7 \mathrm{CR}$ & CCCATRGCTTGYTTRCCCAT & ${ }^{\circ} \mathrm{C} 45 \mathrm{~s}, 72{ }^{\circ} \mathrm{C} 2 \mathrm{~min}$; Cycles of $94{ }^{\circ} \mathrm{C} 45 \mathrm{~s}$, & O 'donnell et al., 2010 \\
\hline & & & $56^{\circ} \mathrm{C} 45 \mathrm{~s}, 72^{\circ} \mathrm{C} 2 \mathrm{~min} ; 72^{\circ} \mathrm{C}$ for $10 \mathrm{~min}$ & \\
\hline & & & Soak $10^{\circ} \mathrm{C}$ & \\
\hline
\end{tabular}

2 $* \mathrm{R}=\mathrm{A}$ or $\mathrm{G} ; \mathrm{S}=\mathrm{C}$ or $\mathrm{G} ; \mathrm{W}=\mathrm{A}$ or $\mathrm{T} ; \mathrm{Y}=\mathrm{C}$ or $\mathrm{T}$. 
Table 2 (on next page)

Isolates and sequences used in this study. 
1 Table 2 Isolates and sequences used in this study.

\begin{tabular}{|c|c|c|c|c|c|c|c|c|}
\hline \multirow{2}{*}{$\begin{array}{l}\text { Species } \\
\text { F. acacia-mearnsii }\end{array}$} & \multicolumn{7}{|c|}{ GenBank accession } & TEF1 \\
\hline & $\begin{array}{l}\text { NRRL } 26755 \\
\text { CBS } 110255 \\
\text { MRC } 5122\end{array}$ & $\begin{array}{l}= \\
=\end{array}$ & Acacia mearnsii & $\begin{array}{l}\text { South } \\
\text { Africa }\end{array}$ & - & KM361640 & KM361658 & AF212449 \\
\hline F. asiaticum & $\begin{array}{lc}\text { NRRL } & 13818 \\
\text { CBS110257 } \\
\text { FRC } & \text { R-5469 } \\
\text { MRC } & 1963 \\
\text { NRRL } & 31547^{\mathrm{T}}\end{array}$ & $\begin{array}{l}= \\
= \\
= \\
=\end{array}$ & Hordeum vulgare & Japan & - & JX171459 & JX171573 & AF212451 \\
\hline F. aywerte & NRRL 25410 & & Soil & Australia & KU171417 & JX171513 & JX171626 & KU171717 \\
\hline F. boothii & $\begin{array}{ll}\text { NRRL } & 26916 \\
\text { ATCC } & \mathbf{2 4 3 7 3} \\
\text { CBS } & \mathbf{3 1 6 . 7 3} \\
\text { NRRL } & \mathbf{2 6 8 5 5 ^ { \mathrm { T } }}\end{array}$ & $\begin{array}{l}= \\
= \\
=\end{array}$ & Zea mays & $\begin{array}{l}\text { South } \\
\text { Africa }\end{array}$ & - & KM361641 & KM361659 & AF212444 \\
\hline F. brachygibbosum & NRRL 34033 & & Human foot & USA & GQ505388 & HМ347172 & GQ505482 & GQ505418 \\
\hline F. coffeatum & $\begin{array}{l}\text { CBS } 635.76 \\
\text { BBA } 62053= \\
\text { NRRL 20841 }\end{array}$ & $=$ & $\begin{array}{l}\text { Cynodon } \\
\text { lemfuensis }\end{array}$ & $\begin{array}{l}\text { South } \\
\text { Africa }\end{array}$ & MN120696 & MN120717 & MN120736 & MN120755 \\
\hline & $\begin{array}{l}\text { CBS } 430.81 \\
\text { NRRL } 28577\end{array}$ & $=$ & Grave stone & Romania & MN120697 & - & MN120737 & MN120756 \\
\hline F. culmorum & $\begin{array}{l}\text { NRRL } 25475 \\
\text { CBS } 417.86= \\
\text { FRC R-8504 } \\
\text { IMI } 309344\end{array}$ & $\begin{array}{l}= \\
=\end{array}$ & Hordeum vulgare & Denmark & - & JX171515 & JX171628 & AF212463 \\
\hline
\end{tabular}




\begin{tabular}{|c|c|c|c|c|c|c|c|}
\hline Species & $\begin{array}{l}\text { Culture } \\
\text { accession }\end{array}$ & Host/substrate & Origin & CAMD & RPB1 & RPB2 & TEF1 \\
\hline F. graminearum & NRRL 36905 & Triticum aestivum & USA & - & KM361646 & KM361664 & DQ459742 \\
\hline \multirow[t]{2}{*}{ F. humicola } & CBS $\quad 124.73=$ & Soil & Pakistan & MN120698 & MN120718 & MN120738 & MN120757 \\
\hline & NRRL $25535^{T}$ & & & & & & \\
\hline \multirow{4}{*}{ F. lacertarum } & ATCC $42771=$ & & & & & & \\
\hline & CBS $130185=$ & & & & & & \\
\hline & IMI $300797^{\mathrm{T}}$ & & & & & & \\
\hline & CBS 127131 & Soil & USA & MN120699 & MN120720 & MN120739 & MN120758 \\
\hline \multirow{4}{*}{ F. lunulosporum } & BBA $62459=$ & & Africa & & & & \\
\hline & CBS 636.76= & & & & & & \\
\hline & FRC R-5822 = & & & & & & \\
\hline & IMI $322097^{\mathrm{T}}$ & & & & & & \\
\hline \multirow[t]{2}{*}{ F. microconidium } & CBS $119843=$ & Unknown & Unknown & MN120700 & MN120721 & - & MN120759 \\
\hline & MRC 839 & & & & & & \\
\hline \multirow[t]{2}{*}{ F. nelsonii } & CBS $119876=$ & Plant debris & South & MN120701 & MN120722 & MN120740 & MN120760 \\
\hline & FRC R $8670=$ & & Africa & & & & \\
\hline \multirow{5}{*}{ F. oxysporum } & & tuberosum & & & & & \\
\hline & CFCC $55679=$ & Hosta ventricosa & China & MW890756 & MZ146450 & MW890757 & MZ088053 \\
\hline & ZE-1b & & & & & & \\
\hline & CFCC 55680= & Hosta ventricosa & China & MW885175 & MZ127817 & MZ126726 & MW885176 \\
\hline & ZE-2b & & & & & & \\
\hline F. peruvianum & CBS 511.75 & Gossypium sp. & Peru & MN120707 & MN120728 & MN120746 & MN120767 \\
\hline F.poae & NRRL 66297 & & - & - & MG282363 & MG282392 & - \\
\hline$F$ & NRRL $28062=$ & Hordeum vulgare & Australia & - & JX171524 & JX171637 & AF212468 \\
\hline \multirow[t]{3}{*}{ pseudograminearum } & CBS 109956= & & & & & & \\
\hline & FRCR 5291= & & & & & & \\
\hline & MAFF $237835^{T}$ & & & & & & \\
\hline \multirow[t]{2}{*}{ F. sibiricum } & NRRL 53429 & Avena sativa & Russia & - & - & HQ154471 & HM744683 \\
\hline & NRRL 53430 ${ }^{\mathrm{T}}$ & Avena sativa & Russia & - & - & HQ154472 & HМ744684 \\
\hline
\end{tabular}




\begin{tabular}{|c|c|c|c|c|c|c|c|}
\hline Species & $\begin{array}{l}\text { Culture } \\
\text { accession }\end{array}$ & Host/substrate & Origin & CAMD & RPB1 & RPB2 & TEF1 \\
\hline \multirow[t]{5}{*}{ F. sporodochiale } & CBS $199.63=$ & Termitary & Unknow & MN120709 & MN120730 & MN120748 & MN120769 \\
\hline & MUCL 6771 & & & & & & \\
\hline & CBS 220.61 = & Soil & South & MN120710 & MN120731 & MN120749 & MN120770 \\
\hline & ATCC $14167=$ & & Africa & & & & \\
\hline & NRRL 20842 & & & & & & \\
\hline F. sporotrichioides & CBS 462.94 & Glycosmis & Austria & MN120711 & MN120732 & MN120750 & MN120771 \\
\hline & & citrifolia & & & & & \\
\hline \multirow[t]{2}{*}{ FIESC 24} & CBS $101138=$ & Phaseolus & Turkey & MN120712 & MN120733 & MN120751 & MN120772 \\
\hline & BBA 70869 & vulgaris & & & & & \\
\hline Fusarium sp. & NRRL 13338 & Soil & Australia & GQ505372 & JX171447 & JX171561 & GQ505402 \\
\hline
\end{tabular}

2 *Isolates in this study. Ex-type cultures are shown in bold. 